\title{
Geographic distribution and risk of upper urothelial carcinomas in Croatia, 2001-2011
}

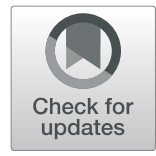

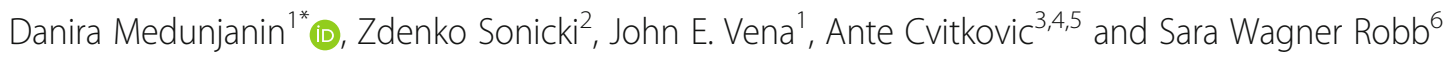

\begin{abstract}
Background: Strong associations exist between Balkan endemic nephropathy (BEN) and upper urothelial carcinomas (UUCs). However, the common etiology between the two remains unclear and there are no studies to date that visualize UUC risks in Croatia. In Croatia, 14 villages in the southwestern part of Brod-Posavina County are considered endemic for BEN. The aim of this ecological study is to map cancer risks and describe the case distribution of UUCs in Croatia at the county level during 2001-2011.

Methods: A total of 608 incident cases from the Croatian National Cancer Registry were identified. Indirect standardization was employed to compute standardized incidence ratios (SIRs).

Results: Counties with SIRs greater than 1 were concentrated around the agricultural region of Slavonia and the coastal region of Dalmatia. However, only Brod-Posavina County and Vukovar-Srijem County had a statistically significant risk of UUC development, where there were 390 and 210\% more UUC cases observed than expected, respectively. Only unique to Brod-Posavina County, females were at higher risk (SIR 4.96; 95\% Cl 3.59-6.34) of developing UUCs than males (SIR 3.03; 95\% Cl 2.04-4.01) when compared to their Croatian counterparts. Although Brod-Posavina County only made up 3.7\% of the total Croatian population (as of 2011), it had the highest frequency of incident UUC cases after the capital City of Zagreb. No elevated cancer risks were noted in the City of Zagreb, even after stratifying by sex.

Conclusion: Our findings suggest that Brod-Posavina County had the highest cancer risk for UUCs, especially among females, when compared to Croatia as a whole during 2001-2011. Given that a majority of BEN patients develop associated UUCS, concurrent screening programs for UUCS and BEN should be considered not only in endemic areas of BEN but also the surrounding rural areas and amongst at-risk groups such as those undergoing hemodialysis, who frequently develop UUCs, to help clarify BEN-UUC associations by identifying common risk factors while standardizing disease estimates across endemic regions for BEN.
\end{abstract}

Keywords: Upper urothelial carcinoma, Balkan endemic nephropathy, Standardized incidence ratio, Geographic information system

\section{Background}

Urothelial carcinomas (UCs) are malignancies of the transitional epithelium that lines the inner surface of the urinary organs including the bladder, urethra, ureter, and renal pelvis [1]. There are two types of UCs; they can either be located in the lower (bladder, urethra) or upper (ureter, renal pelvis) urinary tract [2]. Tumors of the bladder are the most common type; they make up $90-95 \%$ of all UCs $[1,2]$. In contrast, UCs of the upper urinary tract

\footnotetext{
* Correspondence: karzic@musc.edu

${ }^{1}$ Department of Public Health Sciences, Medical University of South Carolina,

Charleston, SC, USA

Full list of author information is available at the end of the article
}

only account for $5-10 \%$ of all UC cases [1-3]. Although rare, $60 \%$ of upper urothelial carcinomas (UUCs) are invasive at diagnosis compared to tumors of the bladder, of which, only $15-25 \%$ are invasive at diagnosis [2]. Moreover, UUCs are more common among people in their senior years (70-90 years of age) and are 2 to 3 times more prevalent among men than women $[2,4,5]$.

The annual incidence of UUCs in Western countries is about $1-2$ cases per 100,000 [2, 4, 5]. Higher frequencies of UUCs have been shown in endemic regions for Balkan endemic nephropathy (BEN), a chronic tubulointerstitial disease that is endemic along the tributaries of the

(c) The Author(s). 2019 Open Access This article is distributed under the terms of the Creative Commons Attribution 4.0 International License (http://creativecommons.org/licenses/by/4.0/), which permits unrestricted use, distribution, and 
Danube River in countries such as Bulgaria, Bosnia and Herzegovina, Serbia, Romania, and Croatia, as early as 40 to 50 years ago [6-13]. In Croatia, 14 villages in the southwestern part of Brod-Posavina County, located in the flood plains of the Sava River, are considered endemic for BEN [9, 14]. Recent findings from several studies suggest a decline in BEN incidence [15-19]; however, conflicting results still exist [20-23]. As for UUC incidence, it appears to be declining according to Markovic et al., who reported a decrease in UUCs over a 30 -year period when endemic areas for BEN were compared to non-endemic areas in Serbia (57.1-fold in $1969-1988$ vs. 11.2 -fold in 1989-1998) [15]. Nonetheless, the risk of UUCs remained high in the BEN endemic areas for 1989-1998 [15].The common etiology between the association of UUCs and BEN remains unclear and there are no studies to date that visualize UUC risks in Croatia. This ecological study aims to map cancer risks and describe the case distribution of UUCs in Croatia at the county level during 2001-2011 using a geographic information system (GIS). Additional comparisons between Brod-Posavina County and the City of Zagreb were made to determine the characteristics of UUCs in endemic and non-endemic counties for BEN.

\section{Methods}

County-level data on the number of newly reported UUC cases obtained from hospital discharge records and notifications from outpatient clinics with histological and cytological findings between 2001 and 2011 through the Croatian National Cancer Registry were analyzed. A total of 608 incident UUC cases from 20 counties (i.e., Bjelovar-Bilogora, BrodPosavina, Dubrovnik-Neretva, Istria, Karlovac, KoprivnicaKrizevci, Krapina-Zagorje, Lika-Senj, Medimurje, OsijekBaranja, Pozega-Slavonia, Primorje-Gorski Kotar, SibenikKnin, Sisak-Moslavina, Split-Dalmatia, Varazdin, ViroviticaPodravina, Vukovar-Srijem, Zadar, and Zagreb County) and the capital City of Zagreb were obtained. Of these Croatian counties, the following five, Brod-Posavina, Osijek-Baranja, Pozega-Slavonia, Virovitica-Podravina and Vukovar-Srijem County correspond to the historical region of Slavonia located east of the country. A UUC case was defined and coded according to the International Classification of Diseases 10th Revision (ICD-10) as any malignant neoplasm of either the renal pelvis (C65), ureter (C66), or any other and unspecified urinary organ (C68). To note, we were unable to distinguish between histological types. However, over 95\% of urinary tract tumors are of the urothelium [24]. The data were stratified according to age, sex, and diagnosis. Age at diagnosis was categorized into 5-year age groups that ranged from 0 to 85 and above while diagnosis was organized into three categories (i.e. the renal pelvis, ureter, and other urinary organs) based on ICD-10 codes.
For descriptive purposes, age at diagnosis was categorized into 4 categories: $<60,60-69,70-79$, and $\geq 80$. Due to limitations in sample size amongst the age strata for each county $(n<20)$, study years were combined (2001-2011). The indirect standardization method was used to estimate the standardized incidence ratio (SIR) with a $95 \%$ confidence interval (CI) for each county by dividing the total number of observed cases by the total number of expected cases. Age-specific UUC reference rates, as per the 2011 Croatian Census from the Croatian Bureau of Statistics, were used in estimating the total number of expected cases. SIRs were stratified by county and sex. A $p$-value of less than 0.05 was considered statistically significant. All results were computed using SAS 9.4 (Cary, NC: SAS Institute Inc.). A map was generated to display SIRs at the county-level using QGIS version 3.2.0.

\section{Results}

A total of 608 UUC cases were identified in Croatia during 2001-2011, of which, 55.4\% were males (Table 1). Conversely, in Brod-Posavina County incident UUC cases were predominantly female $(58.1 \%)$. More than half $(61.6 \%)$ of all UUC cases in Brod-Posavina County and $43.3 \%$ in Croatia were in their 70 s at the time of diagnosis. In the City of Zagreb, UUC cases were significantly younger $(p=0.0001)$ than those in Brod-Posavina County.

Fifty-three percent of all UUC cases in Croatia were tumors of the renal pelvis followed by the ureter (33.9\%) and other urinary organs (12.7\%). No differences in diagnoses were noted between Brod-Posavina County and the City of Zagreb.

The City of Zagreb had the highest frequency of incident UUC cases in 2001-2011 followed by BrodPosavina County and Split-Dalmatia County (Table 2). Counties with SIRs greater than 1 were concentrated around the eastern agricultural region of Slavonia and the southern coastal region of Dalmatia (Fig. 1). However, only two Slavonian counties, Brod-Posavina County and Vukovar-Srijem County, had a statistically significant risk of UUC development, where there were 390 and $210 \%$ more UUC cases observed than expected, respectively. Moreover, males and females in BrodPosavina County had a 3 -fold and 5-fold increased UUC risk compared to their Croatian counterparts (Table 3). No elevated cancer risks were observed in the City of Zagreb, even after stratifying by sex.

\section{Discussion}

Our main results demonstrate a 3.9-fold increased risk for UUCs in Brod-Posavina County in comparison to Croatia during the 10-year period. Our findings were in accordance with earlier studies conducted in Croatia 
Table 1 Characteristics of incident upper urothlial carcinoma cases in Croatia, Brod-Posavina County, and the City of Zagreb, 20012011

\begin{tabular}{|c|c|c|c|c|}
\hline & Croatia & Brod-Posavina County & City of Zagreb & $p$-value \\
\hline $\mathrm{N}$ & 608 & 86 & 107 & \\
\hline Sex $\%$ Male & 55.4 & 41.9 & 55.1 & 0.0823 \\
\hline \multicolumn{5}{|l|}{ Age at Diagnosis $n(\%)$} \\
\hline$<60$ & $105(17.3)$ & $6(7.0)$ & $22(20.5)$ & \multirow[t]{4}{*}{0.0001} \\
\hline $60-69$ & $170(27.9)$ & $15(17.4)$ & $37(34.6)$ & \\
\hline $70-79$ & $263(43.3)$ & $53(61.6)$ & $34(31.8)$ & \\
\hline$\geq 80$ & $70(11.5)$ & $12(14.0)$ & $14(13.1)$ & \\
\hline \multicolumn{5}{|l|}{ Diagnosis n (\%) } \\
\hline Renal Pelvis & $325(53.4)$ & $43(50.0)$ & $57(53.3)$ & \multirow[t]{3}{*}{0.7970} \\
\hline Ureter & $206(33.9)$ & $29(33.7)$ & $36(33.6)$ & \\
\hline Other Urinary Organs & $77(12.7)$ & $14(16.3)$ & $14(13.1)$ & \\
\hline
\end{tabular}

${ }^{a}$ Fisher Exact test two-sided p-value comparing Brod-Posavina County to City of Zagreb

Table 2 Standardized incidence ratios for upper urothelial carcinomas by county and the City of Zagreb, 2001-2011

\begin{tabular}{|c|c|c|c|}
\hline & Observed & Expected & $\operatorname{SIR}(95 \% \mathrm{Cl})$ \\
\hline Brod-Posavina County ${ }^{c}$ & 86 & 22.1 & $3.90(3.08,4.72)^{b}$ \\
\hline Vukovar-Srijem County ${ }^{c}$ & 52 & 24.8 & $2.10(1.53,2.67)^{a}$ \\
\hline Dubrovnik-Neretva County & 22 & 17.4 & $1.27(0.74,1.80)$ \\
\hline Split-Dalmatia County & 68 & 61.3 & $1.11(0.85,1.37)$ \\
\hline Karlovac County & 23 & 21.0 & $1.10(0.65,1.54)$ \\
\hline Osijek-Baranja County ${ }^{c}$ & 45 & 42.0 & $1.07(0.76,1.38)$ \\
\hline City of Zagreb & 107 & 108.8 & $0.98(0.80,1.17)$ \\
\hline Virovitica-Podravina County ${ }^{c}$ & 11 & 11.8 & $0.93(0.38,1.48)$ \\
\hline Primorje-Gorski Kotar County & 38 & 45.6 & $0.83(0.57,1.10)$ \\
\hline Istria County & 25 & 30.4 & $0.82(0.50,1.15)$ \\
\hline Sisak-Moslavina County & 22 & 26.8 & $0.82(0.48,1.17)$ \\
\hline Pozega-Slavonia County ${ }^{c}$ & 9 & 11.1 & $0.81(0.28,1.35)$ \\
\hline Zadar County & 20 & 25.0 & $0.80(0.45,1.15)$ \\
\hline Medimurje County & 10 & 14.4 & $0.69(0.26,1.12)$ \\
\hline Koprivnica-Krizevci County & 11 & 16.4 & $0.67(0.27,1.07)$ \\
\hline Lika-Senj County & 6 & 9.30 & $0.64(0.13,1.16)$ \\
\hline Bjelovar-Bilogora County & 11 & 17.6 & $0.63(0.26,0.99)^{a}$ \\
\hline Sibenik-Knin County & 10 & 18.4 & $0.54(0.21,0.88)^{a}$ \\
\hline Zagreb County & 16 & 41.5 & $0.39(0.20,0.57)^{b}$ \\
\hline Varazdin County & 9 & 23.8 & $0.38(0.13,0.62)^{b}$ \\
\hline Krapina-Zagorje County & 7 & 18.6 & $0.38(0.10,0.65)^{b}$ \\
\hline
\end{tabular}

The standard population used was the 2011 Croatian Census

$S I R$ standardized incidence ratio, $\mathrm{Cl}$ confidence interval

${ }^{\mathrm{a}} p<0.05$

b $p<0.0001$

c The following Croatian counties correspond to the historical region of Slavonia where BEN is prevalent $[6,11,14]$. Similarly, Cvitkovic et al. reported a 4.6-fold UUC risk in Brod-Posavina County during 2003-2009 [14]. As for the City of Zagreb, no elevated cancer risks for UUCs were noted for the total study period, even after stratifying by sex. Though the prevalence of BEN has declined over the years in Brod-Posavina County [18], the risk of UUC development remains high according to our data. This drop in prevalence may be due to either a low incidence in BEN, indicating a reduction in exposure activity, or a high case-fatality [18]. The latter can be ruled out since more and more people are living longer with BEN than in the past [18]. Today, BEN is commonly detected in the 6th decade of life [25]. Underreporting and migration could also explain some of the drops in registered BEN cases. From our map, we noted counties along the coast having greater than expected frequencies of incident UUCs. Though our findings in Dalmatia were nonsignificant, it is possible that residents of Slavonia sought employment in the tourism sector along the coast during the 2008 economic crisis. Unemployment in Slavonia was about $130-180 \%$ higher than the national average and an estimated 35,000 residents migrated elsewhere in the country during our study period [26].

Renal pelvic tumors are about twice as common than those of the ureter $[2,5]$. Despite no differences in diagnosis, a third of all UUC cases in Croatia including Brod-Posavina County and the City of Zagreb were tumors of the ureter. Though it remains a matter of clinical debate $[27,28]$, several single and multicenter studies have shown ureteral tumors to have a worse prognosis than those of the renal pelvis after treatment with nephroureterectomy [29-31]. Incident cases of UUCs in Brod-Posavina County were predominately female (58\%) and tended to be significantly older at the time of diagnosis than those in the City of Zagreb. 


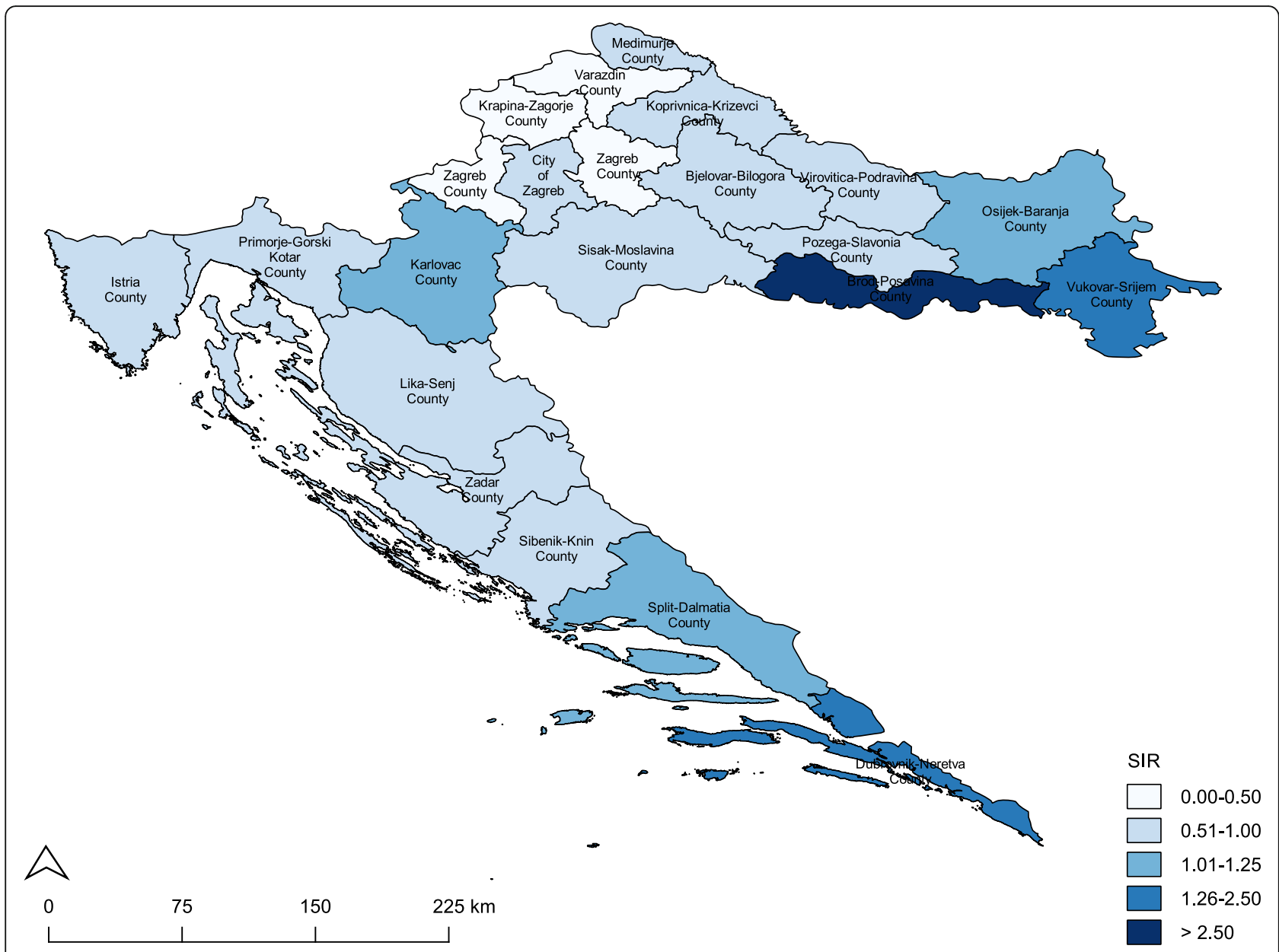

Fig. 1 Map of standardized incidence ratios for upper urothelial carcinomas in Croatia by county and the City of Zagreb, $2001-2011$

Females in Brod-Posavina County were also at higher risk of developing UUCs than males when compared to their Croatian counterparts. Even after stratifying by sex, there were no elevated cancer risks in the City of Zagreb. Our findings are contrary to Western countries, where UUCs are 2 to 3 times more prevalent among

Table 3 Standardized incidence ratios for upper urothelial carcinomas in Brod-Posavina County and the City of Zagreb, $2001-2011$

\begin{tabular}{lcll}
\hline & Observed & Expected & SIR $(95 \% \mathrm{Cl})$ \\
\hline Brod-Posavina County & & \\
Males & 36 & 11.9 & $3.03(2.04,4.01)^{\mathrm{a}}$ \\
Females & 50 & 10.1 & $4.96(3.59,6.34)^{\mathrm{a}}$ \\
$\begin{array}{l}\text { City of Zagreb } \\
\text { Males }\end{array}$ & 59 & 58.9 & $1.00(0.74,1.25)$ \\
Females & 48 & 49.0 & $0.98(0.70,1.26)$ \\
\hline
\end{tabular}

The standard population used was the 2011 Croatian Census

$S I R$ standardized incidence ratio, $\mathrm{Cl}$ confidence interval

${ }^{\mathrm{a}} p<0.0001$ males $[2,4,5]$. It appears that female predominance regarding UUC incidence is unique to endemic regions of $\operatorname{BEN}[6,11,14,32]$. This may be related to differences in timing of diagnosis and disease progression given that the male-to-female ratio of dying from an UUC in BrodPosavina County is 2:1 [14].

A limitation in our study was our inability to compare incidence rates directly between counties due to an insufficient sample size. In most cases, indirect standardized rates are not comparable when age structures of populations differ [33]. SIRs can only be compared with their respective standard population and not with each other due to their given weights used to generate each ratio [33]. Additionally, county of residence was limited to time of diagnosis. Therefore, we were unable to assess the cumulative effect of length of residence in a particular county on UUC risk. This is especially of value for Brod-Posavina County, where a residence of over 20 years in an endemic household or village is required to establish a BEN diagnosis [34]. It is possible that residents of Brod-Posavina County migrated elsewhere during our study period. 
Given this, our SIRs for Brod-Posavina County may be underestimated. Finally, information on tumor grade and stage was unavailable to us in this study. Pathologically, both are known to influence the survival of UUC patients after treatment surgery $[2,5,27]$. In the past, lower grade and stage tumors were unique to UUC patients from BEN endemic regions resulting in a more conservative approach of treatment $[13,35]$. This is no longer the case. Comparative studies of UUC patients from BEN endemic and non-endemic areas of Serbia describe a more aggressive pattern of tumor behavior in both [36, 37]. Though we no longer see differences in tumor behavior between BEN endemic and non-endemic regions [35, 38], more UUC patients from regions endemic to BEN are presenting with higher grade and stage tumors at diagnosis than ever before [35]. This may be attributed to the disease itself, changes in treatment practice, or our ability to detect it at an earlier stage. Therefore, investigations of temporal trends in tumor behavior of UUC patients in Croatia are warranted.

Conflicting BEN estimates amongst the endemic foci continue to exist [16-23]. This is, in part, due to the adaptation of different sets of diagnostic criteria over the years. Subsequently, this has led to the indiscriminate use of different parameters and cutoff values for the identification of BEN cases. Recently, a consensus statement was created in 2013 by a panel of experts from the "International Workshop on Diagnostic Criteria on Endemic Nephropathy" to address some of these issues [34]. Future epidemiologic studies should identify regional differences, question their capacity to perform BEN-UUC related research, and rule out local characteristics unique to the endemic foci as well as evaluate methods of case ascertainment prior to assuming true changes in BEN.

Our study is the first to visualize a consistently high cancer risk for UUCs during 2001-2011, especially among females in Brod-Posavina County. Although Brod-Posavina County only made up $3.7 \%$ of the total Croatian population (as of 2011), it had the highest frequency of incident UUC cases after the City of Zagreb. It is important to note, that the two counties with significant cancer risks for UUCs are in Slavonia along the Sava River and border Bosnia and Herzegovina. Furthermore, our findings reinforce the apparent geographical association between BEN and UUCs; thus, suggesting a common etiology that may be multifactorial in nature, involving both genetic and environmental factors, due to evidence of familial clustering [39] and disease development after migrating to the endemic foci, such as in the case of the Ukrainian immigrants who settled in the endemic villages of Brod-Posavina County [40]. Numerous etiological agents for BEN have been proposed over the years, including heavy metals and mycotoxins (i.e., ochratoxin A) [41]. However, none warrant enough scientific evidence for establishing causality. The most prominent risk factor for BEN is dietary exposure to aristolochic acid (AA) in bread from seeds of Aristolochia clematitis comingling with wheat grain [42, 43]. However, this dietary route of exposure remains questionable given the lack of temporality between the presence of ripe $A$. clematitis seeds and when wheat is harvested $[44,45]$ as well as the amount and time of exposure to dietary AA needed to develop BEN (i.e., eating bread daily with at least seven mature seeds of $A$. clematitis for the past seven decades) [45, 46]. Unfortunately, the role of AA in the etiology of BEN was not pursued by the scientific community until the early 1990s when a high incidence of rapidly progressive tubulointerstitial renal disease was reported among a group of Belgian women who were taking herbal dietary supplements that accidentally contained Aristolochia fangchi, an Aristolochia species [47]. Almost half of the women developed associated UUCs within a few years [41]. Despite the longer duration period (15-20 years) needed to develop BEN, both AA-induced nephropathy (AAN) and BEN resemble one another in terms of their clinical manifestations and pathophysiology [41, 48-50]. This has led to the hypothesis of a common etiological agent, dietary exposure to AA, which may act as an environmental risk factor for BEN and its associated UUCs. Improvements in harvesting and milling technologies have been attributed to the reduction of AA exposure and the subsequent declines in BEN incidence [18, 43, 51].

\section{Conclusion}

In conclusion, our findings provide novel insights into the geographic distribution of UUC risk, demonstrating a 3.9fold increased risk of UUC development, especially among females, in Brod-Posavina County when compared to Croatia as a whole, and should serve as preliminary data for future UUC and BEN-related research in Croatia. Given that many BEN patients develop associated UUCs, concurrent screening programs for UUCs and BEN should be considered, not only in endemic areas of BEN but also the surrounding rural areas and amongst at-risk groups such as those undergoing hemodialysis, who frequently develop UUCs [52, 53]. This would help to clarify BEN-UUC associations by identifying common risk factors while standardizing disease estimates across endemic regions for BEN.

\section{Abbreviations \\ AA: Aristolochic acid; BEN: Balkan endemic nephropathy; Cl: Confidence interval; GIS: Geographic information system; SIR: Standardized incidence ratio; UUC: Upper urothelial carcinoma}

\footnotetext{
Acknowledgements

The authors would like to thank Dr. Carol Cotton, Dr. Lawrence Phillips and Mrs. Sarah Phillips, and the UGA-Croatia Partnership Fund for supporting the MPH student internship. A special thanks to Dr. Marijan Erceg and Dr. Tamara Poljicanin for helping us receive ethical approval from the ethics committee of the Croatian National Institute of Public Health and Dr. Mario Sekerija and the Croatian National Cancer Registry for providing us the data.
} 


\section{Authors' contributions}

DM contributed to the study conception and design, acquired the data, performed the statistical analysis, and led the drafting of the manuscript. ZS contributed to the study conception and design, acquired the data, assisted in the statistical analysis, helped interpret the results, and revised the manuscript. JEV contributed to the study conception and design, helped interpret the results and expand the discussion, and revised the manuscript AC contributed to the study conception and design, acquired the data, provided expert oversight on the topic, and revised the manuscript. SWR contributed to the study conception and design, helped with the statistical analysis and mapping, and revised the manuscript critically for important intellectual content. All authors read and approved the final manuscript.

\section{Funding}

The research reported here was not funded. This study was the product of a Masters of Public Health (MPH) program student internship in Croatia and capstone project from the University of Georgia (UGA), College of Public Health, Department of Epidemiology and Biostatistics.

\section{Availability of data and materials}

The datasets used and/or analysed during the current study are available from the corresponding author on reasonable request.

\section{Ethics approval and consent to participate}

The Institutional Review Board at the University of Georgia approved this study. Ethical approval for data use from the Croatian National Cancer Registry was obtained from the ethics committee of the Croatian National Institute of Public Health.

\section{Consent for publication}

Not applicable.

\section{Competing interests}

The authors declare that they have no competing interests.

\section{Author details}

${ }^{1}$ Department of Public Health Sciences, Medical University of South Carolina, Charleston, SC, USA. ${ }^{2}$ University of Zagreb, School of Medicine, Andrija Stampar School of Public Health, Zagreb, Croatia. ${ }^{3}$ Institute for Public Health, Brodsko Posavska County, Slavonski Brod, Croatia. ${ }^{4}$ Josip Juraj Strossmayer University of Osijek, Faculty of Medicine, Osijek, Croatia. ${ }^{5}$ Josip Juraj Strossmayer University of Osijek, Faculty of Dental Medicine and Health Osijek, Croatia. ${ }^{6}$ Department of Public Health Sciences, Clemson University, Clemson, SC, USA.

\section{Received: 5 February 2019 Accepted: 13 September 2019}

\section{Published online: 15 October 2019}

\section{References}

1. Tyler A. Urothelial cancers: ureter, renal pelvis, and bladder. Semin Oncol Nurs. 2012;28(3):154-62.

2. Roupret M, Babjuk M, Comperat E, Zigeuner R, Sylvester RJ, Burger M, et al. European association of urology guidelines on upper urinary tract Urothelial carcinoma: 2017 update. Eur Urol. 2018;73(1):111-22.

3. Munoz JJ, Ellison LM. Upper tract urothelial neoplasms: incidence and survival during the last 2 decades. J Urol. 2000;164(5):1523-5.

4. Lughezzani G, Sun M, Perrotte P, Shariat SF, Jeldres C, Budaus L, et al. Gender-related differences in patients with stage I to III upper tract urothelial carcinoma: results from the surveillance, epidemiology, and end results database. Urology. 2010;75(2):321-7.

5. Roupret M, Babjuk M, Comperat E, Zigeuner R, Sylvester RJ, Burger M, et al. European Association of Urology guidelines on upper urinary tract Urothelial cell carcinoma: 2015 update. Eur Urol. 2015;68(5):868-79.

6. Belicza M, Demirovic A, Tomic K, Lenicek T, Pavic I, Jakovina K, et al. Comparison of occurrence of upper urinary tract carcinomas in the region with endemic villages and non-endemic nephropathy region in Croatia. Coll Antropol. 2008;32(4):1203-7.

7. Cukuranovic R, Ignjatovic M, Stefanovic V. Urinary tract tumors and Balkan nephropathy in the South Morava River basin. Kidney Int Suppl. 1991;34:S80-4.
8. Gluhovschi G, Margineanu F, Velciov S, Gluhovschi C, Bob F, Petrica L, et al. Fifty years of Balkan endemic nephropathy in Romania: some aspects of the endemic focus in the Mehedinti county. Clin Nephrol. 2011;75(1):34-48.

9. Miletic-Medved M, Domijan AM, Peraica M. Recent data on endemic nephropathy and related urothelial tumors in Croatia. Wien Klin Wochenschr. 2005;117(17):604-9.

10. Petronic VJ, Bukurov NS, Djokic MR, Milenkovic DZ, Vuksanovic AM, Avramovic AD, et al. Balkan endemic nephropathy and papillary transitional cell tumors of the renal pelvis and ureters. Kidney Int Suppl. 1991;34:S77-9.

11. Sostaric B, Vukelic M. Characteristics of urinary tract tumours in the area of Balkan endemicnephropathy in Croatia. IARC Sci Publ. 1991;115:29-35.

12. Stefanovic V, Polenakovic M, Toncheva D. Urothelial carcinoma associated with Balkan endemic nephropathy. A worldwide disease. Pathol Biol (Paris). 2011;59(5):286-91.

13. Stefanovic V, Radovanovic Z. Balkan endemic nephropathy and associated urothelial cancer. Nat Clin Pract Urol. 2008;5(2):105-12.

14. Cvitkovic A, Ivic-Hofman I, Juric D. Upper urothelium carcinomas in Croatian endemic area. Wien Klin Wochenschr. 2013;125(17-18):529-36.

15. Markovic N, Ignjatovic I, Cukuranovic R, Petrovic B, Kocic B, Stefanovic V. Decreasing incidence of urothelial cancer in a Balkan endemic nephropathy region in Serbia. A surgery based study from 1969 to 1998. Pathol Biol (Paris). 2005;53((1):26-9.

16. Dimitrov PS, Simeonov VA, Stein AD. Balkan endemic nephropathy in Vratza, Bulgaria, 1964-1987: an epidemiologic analysis of population-based disease registers. Eur J Epidemiol. 2001;17(9):847-53.

17. Dimitrov PS, Simeonov VA, Ganev VS, Karmaus WJ. Is the incidence of Balkan endemic nephropathy decreasing? Pathol Biol (Paris). 2002;50(1):38-41.

18. Cvitkovic A, Vukovic-Lela I, Edwards KL, Karanovic S, Juric D, Cvoriscec D, et al. Could disappearance of endemic (Balkan) nephropathy be expected in forthcoming decades? Kidney Blood Press Res. 2012;35(3):147-52.

19. Cukuranovic R, Petrovic B, Cukuranovic Z, Stefanovic V. Balkan endemic nephropathy: a decreasing incidence of the disease. Pathol Biol (Paris). 2000; 48(6):558-61.

20. Bukvic D, Jankovic S, Arsenovic A, Djukanovic L. Balkan endemic nephropathy is still present in the Kolubara region. Serbia Ren Fail. 2005;27(5):565-9.

21. Bukvic D, Maric I, Arsenovic A, Jankovic S, Djukanovic L. Prevalence of Balkan endemic nephropathy has not changed since 1971 in the Kolubara region in Serbia. Kidney Blood Press Res. 2007;30(2):117-23.

22. Jankovic S, Bukvic D, Marinkovic J, Jankovic J, Maric I, Djukanovic L. Time trends in Balkan endemic nephropathy incidence in the most affected region in Serbia, 1977-2009: the disease has not yet disappeared. Nephrol Dial Transplant. 2011;26(10):3171-6.

23. Jankovic S, Bukvic D, Marinkovic J, Jankovic J, Maric I, Djukanovic L. Trends in incidence and prevalence of Balkan endemic nephropathy in the three most affected villages in Serbia over a 36-year period. Ren Fail. 2013;35(4):509-13.

24. Roupret M, Babjuk M, Comperat E, Zigeuner R, Sylvester R, Burger M, et al. European guidelines on upper tract urothelial carcinomas: 2013 update. Eur Urol. 2013;63(6):1059-71.

25. Stefanovic V, Cukuranovic R, Miljkovic S, Marinkovic D, Toncheva D. Fifty years of Balkan endemic nephropathy: challenges of study using epidemiological method. Ren Fail. 2009;31(5):409-18.

26. Rácz S. Regional development in Croatia from the turn of millennium to the EU accession. Reg Stat. 2014;4(2):71-86.

27. Lughezzani G, Burger M, Margulis V, Matin SF, Novara G, Roupret M, et al. Prognostic factors in upper urinary tract urothelial carcinomas: a comprehensive review of the current literature. Eur Urol. 2012;62(1):100-14.

28. Williams AK, Kassouf W, Chin J, Rendon R, Jacobsen N, Fairey A, et al. Multifocality rather than tumor location is a prognostic factor in upper tract urothelial carcinoma. Urol Oncol. 2013;31(7):1161-5.

29. Akdogan B, Dogan HS, Eskicorapci SY, Sahin A, Erkan I, Ozen H. Prognostic significance of bladder tumor history and tumor location in upper tract transitional cell carcinoma. J Urol. 2006;176(1):48-52.

30. Ouzzane A, Colin P, Xylinas E, Pignot G, Ariane MM, Saint F, et al. Ureteral and multifocal tumours have worse prognosis than renal pelvic tumours in urothelial carcinoma of the upper urinary tract treated by nephroureterectomy. Eur Urol. 2011;60(6):1258-65.

31. Yafi FA, Novara G, Shariat SF, Gupta A, Matsumoto K, Walton TJ, et al. Impact of tumour location versus multifocality in patients with upper tract urothelial carcinoma treated with nephroureterectomy and bladder cuff excision: a homogeneous series without perioperative chemotherapy. BJU Int. 2012;110(2 Pt 2):E7-13. 
32. Ceovic S, Plestina R, Miletic-Medved M, Stavljenic A, Mitar J, Vukelic M. Epidemiological aspects of Balkan endemic nephropathy in a typical focus in Yugoslavia. IARC Sci Publ. 1991;115:5-10.

33. Health Alo, Welfare. Principles on the Use of Direct Age-standardisation in Administrative Data Collections: For Measuring the Gap Between Indigenous and Non-Indigenous Australians 2011.

34. Jelakovic B, Nikolic J, Radovanovic Z, Nortier J, Cosyns JP, Grollman AP, et al. Consensus statement on screening, diagnosis, classification and treatment of endemic (Balkan) nephropathy. Nephrol Dial Transplant. 2014;29(11):2020-7.

35. Cukuranovic R, Ignjatovic I, Visnjic M, Velickovic L, Petrovic B, Potic M, et al. Characteristics of upper urothelial carcinoma in an area of Balkan endemic nephropathy in South Serbia. A fifty-year retrospective study. Tumori. 2010; 96(5):674-9.

36. Dragicevic D, Djokic M, Pekmezovic T, Micic S, Hadzi-Djokic J, Vuksanovic A, et al. Survival of patients with transitional cell carcinoma of the ureter and renal pelvis in Balkan endemic nephropathy and non-endemic areas of Serbia. BJU Int. 2007;99(6):1357-62.

37. Velickovic L, Hattori T, Dolicanin Z, Visnjic M, Krstic M, llic I, et al. Upper urothelial carcinoma in Balkan endemic nephropathy and non-endemic regions: a comparative study of pathological features. Pathol Res Pract. 2009:205(2):89-96.

38. Samardzic J, Hasukic S. Upper urinary tract Urothelial Cancer in Croatian and Bosnian endemic nephropathy regions. Med Arch. 2017;71(6):430-3.

39. Pavlovic NM. Balkan endemic nephropathy-current status and future perspectives. Clin Kidney J. 2013;6(3):257-65.

40. Ceovic S, Hrabar A, Radonic M. An etiological approach to Balkan endemic nephropathy based on the investigation of two genetically different populations. Nephron. 1985;40(2):175-9.

41. Stiborova M, Arlt VM, Schmeiser HH. Balkan endemic nephropathy: an update on its aetiology. Arch Toxicol. 2016;90(11):2595-615.

42. Ivić M. Etiology of endemic nephropathy. Lijecnicki vjesnik. 1969;91 (12):1273.

43. Hranjec T, Kovac A, Kos J, Mao W, Chen JJ, Grollman AP, et al. Endemic nephropathy: the case for chronic poisoning by aristolochia. Croat Med J. 2005:46(1):116-25.

44. Pepeljnjak S, Klaric MS. Suspects in etiology of endemic nephropathy: aristolochic acid versus mycotoxins. Toxins (Basel). 2010:2(6):1414-27.

45. Mantle $P G$, Herman D, Tatu C. Is Aristolochic acid really the cause of the Balkan endemic nephropathy? J Controversies Biomed Res. 2016;2(1):9-20.

46. Mantle P, Modalca M, Nicholls A, Tatu C, Tatu D, Toncheva D. Comparative (1)H NMR metabolomic urinalysis of people diagnosed with Balkan endemic nephropathy, and healthy subjects, in Romania and Bulgaria: a pilot study. Toxins (Basel). 2011;3(7):815-33.

47. Vanherweghem JL, Depierreux M, Tielemans C, Abramowicz D, Dratwa M, Jadoul $\mathrm{M}$, et al. Rapidly progressive interstitial renal fibrosis in young women: association with slimming regimen including Chinese herbs. Lancet. 1993;341 (8842):387-91.

48. Cosyns JP, Jadoul M, Squifflet JP, De Plaen JF, Ferluga D, van Ypersele de Strihou C. Chinese herbs nephropathy: a clue to Balkan endemic nephropathy? Kidney Int. 1994:45(6):1680-8.

49. De Broe ME. Chinese herbs nephropathy and Balkan endemic nephropathy: toward a single entity, aristolochic acid nephropathy. Kidney Int. 2012;81(6):513-5.

50. Debelle FD, Vanherweghem JL, Nortier JL. Aristolochic acid nephropathy: a worldwide problem. Kidney Int. 2008;74(2):158-69.

51. Jelakovic B, Vukovic Lela I, Karanovic S, Dika Z, Kos J, Dickman K, et al. Chronic dietary exposure to aristolochic acid and kidney function in native farmers from a Croatian endemic area and Bosnian immigrants. Clin J Am Soc Nephrol. 2015;10(2):215-23.

52. Stewart JH, Buccianti G, Agodoa L, Gellert R, McCredie MR, Lowenfels AB, et al. Cancers of the kidney and urinary tract in patients on dialysis for endstage renal disease: analysis of data from the United States, Europe, and Australia and New Zealand. J Am Soc Nephrol. 2003;14(1):197-207.

53. Cuckovic C, Djukanovic L, Jankovic S, Stanojcic A, Dragicevic P, Radmilovic A, et al. Malignant tumors in hemodialysis patients. Nephron. 1996;73(4):710-2.

\section{Publisher's Note}

Springer Nature remains neutral with regard to jurisdictional claims in published maps and institutional affiliations.

\section{Ready to submit your research? Choose BMC and benefit from:}

- fast, convenient online submission

- thorough peer review by experienced researchers in your field

- rapid publication on acceptance

- support for research data, including large and complex data types

- gold Open Access which fosters wider collaboration and increased citations

- maximum visibility for your research: over $100 \mathrm{M}$ website views per year

At $\mathrm{BMC}$, research is always in progress.

Learn more biomedcentral.com/submissions 